\title{
PULMONARY DIFFUSING CAPACITY DURING REST AND EXERCISE. A STUDY OF NORMAL PERSONS AND PERSONS WITH ATRIAL SEPTAL DEFECT, PREGNANCY, AND PULMONARY DISEASE *
}

\author{
By GEORGE N. BEDELL AND RICHARD W. ADAMS
}

(From the Pulmonary Laboratory, Cardiovascular Research Laboratories, Department of Internal Medicine, College of Medicine, State University of Iowa, Iowa City, Iowa)

(Submitted for publication April 26, 1962; accepted June 22, 1962)

The pulmonary diffusing capacity of normal persons increases during exercise, and has been measured by many investigators and by a variety of techniques (2-7). This increase in pulmonary diffusing capacity is probably caused by an increase in the size of the pulmonary capillary bed (8), but the mechanism by which it occurs is incompletely understood. It is independent of pulmonary blood flow $(7,9)$, but is related to the pressure across the walls of the pulmonary blood vessels (10). If the increase in pulmonary diffusing capacity in response to exercise is caused by enlargement of the pulmonary capillary bed, an increase in pulmonary diffusing capacity ought to be demonstrated regularly in persons with a normal capillary bed, and a failure to increase in a normal fashion ought to be demonstrated in some patients with a restricted vascular bed.

The purpose of our investigation was 1) to determine the magnitude of increase in pulmonary diffusing capacity in normal subjects at various levels of exercise, 2) to ascertain the extent of exercise needed to give a predictable increase in pulmonary diffusing capacity in normal subjects, and 3) to study the exercise response of pulmonary diffusing capacity in subjects with a pulmonary capillary bed of normal size, as in pregnancy, patients with a large resting pulmonary capillary bed, as with atrial septal defect, and patients with a restricted pulmonary capillary bed, as in lung disease.

* Presented in part at the Midwestern Section Meeting of the American Federation for Clinical Research, Chicago, Ill., November 2, 1961 (1) ; supported by a research grant H-3304 from the National Heart Institute, U. S. Public Health Service, and aided by grants from the Iowa Tuberculosis and Health Association and the Iowa Heart Association.

\section{MATERIALS AND METHODS}

The nine normal subjects were medical students or laboratory technicians with no history of heart or lung disease; their physical characteristics are given in Table I. They were exercised on a motor driven treadmill at five grades of exercise: 2,3 , and 4 miles per hour, 4 miles per hour with an 8 per cent grade, and $4 \frac{1}{2}$ miles per hour with an 8 per cent grade. Exercise continued for 7 minutes. Pulmonary diffusing capacity was determined by the single breath method of Ogilvie, Forster, Blakemore, and Morton (6) at 2, 4, and 6 minutes of exercise. The three values of pulmonary diffusing capacity thus obtained were averaged to obtain the value of diffusing capacity for a given level of exercise. Our results were similar to those of Ogilvie and colleagues (6) in that these three values tended to be close together. Each time that the response of a subject to exercise was studied, a resting diffusing capacity was determined before exercise. The subjects sat quietly for 20 minutes and then three determinations of resting diffusing capacity were made. The resting diffusing capacity was an average of the three determinations. Since resting values vary from day to day, it was necessary to determine the resting value and the exercise value at each level of exercise studied. In performing the breathholding diffusing capacity test, each subject was instructed to take a maximal inspiration. Alveolar volumes at rest and exercise were similar, thus obviating

TABLE I

Some physical characteristics of normal persons

\begin{tabular}{cccccc}
\hline \hline Subject & Age & Sex & Height & Weight & $\begin{array}{c}\text { Body } \\
\text { surface } \\
\text { area }\end{array}$ \\
\hline & years & & inches & pounds & $m^{2}$ \\
N.A. & 20 & F & 65 & 109 & 1.53 \\
D.S. & 22 & F & 66 & 156 & 1.80 \\
S.D. & 24 & F & 65 & 109 & 1.53 \\
M.S. & 35 & F & 65 & 125 & 1.60 \\
P.B. & 17 & M & 66 & 156 & 1.80 \\
R.C. & 20 & M & 73 & 163 & 1.94 \\
R.A. & 22 & M & 71 & 162 & 1.91 \\
S.J. & 29 & M & 70 & 170 & 1.94 \\
R.R. & 30 & M & 69 & 179 & 1.96 \\
& & & & &
\end{tabular}


differences caused by variation in alveolar volume (1115).

Oxygen consumption was determined for the various levels of exercise. The subjects walked on the treadmill for 9 minutes. Diffusing capacity was measured during the first 7 minutes, and oxygen consumption during the last 2. Expired air was collected between the seventh and ninth minutes for calculation of oxygen consumption. Sometimes the measurements of oxygen consumption were made at a different time from those of diffusing capacity. In these cases, the patient walked on the treadmill for 9 minutes, and oxygen consumption was measured between the seventh and ninth minutes. Expired air was collected in a Douglas bag and was analyzed for oxygen with a Beckman $E_{2}$ analyzer, and for carbon dioxide with a Beckman model 15 infrared analyzer. Minute volume was expressed at standard temperature and pressure, dry (STPD).

The age, body surface area, and duration of pregnancy of the eleven pregnant women are listed in Table II. These women had no symptoms of heart or lung disease. Pulmonary diffusing capacity was determined in the
TABLE II

Some physical characteristics and results of pulmonary function studies in pregnant women

\begin{tabular}{|c|c|c|c|c|c|c|}
\hline \multirow[b]{2}{*}{ Subject } & \multirow[b]{2}{*}{ Age } & \multirow[b]{2}{*}{$\begin{array}{l}\text { Body } \\
\text { surface } \\
\text { area }\end{array}$} & \multirow[b]{2}{*}{$\begin{array}{l}\text { Dura- } \\
\text { tion of } \\
\text { pregnancy }\end{array}$} & \multicolumn{3}{|c|}{$\begin{array}{l}\text { Pulmonary diffusing } \\
\text { capacity } \\
\text { (ml CO/mmHg/min) }\end{array}$} \\
\hline & & & & & Rest & $\begin{array}{l}\text { Exer- } \\
\text { cise } \\
3 \mathrm{mph}\end{array}$ \\
\hline & years & $m^{2}$ & weeks & & & \\
\hline \multirow[t]{2}{*}{$\begin{array}{l}\text { S.B. } \\
\text { R.C. } \\
\text { L.H. } \\
\text { L.M. } \\
\text { M.P. } \\
\text { R.V. } \\
\text { B.B. } \\
\text { R.L. } \\
\text { V.G. } \\
\text { R.W. } \\
\text { B.H. }\end{array}$} & $\begin{array}{l}21 \\
22 \\
22 \\
22 \\
24 \\
24 \\
25 \\
25 \\
26 \\
26 \\
31\end{array}$ & $\begin{array}{l}1.72 \\
1.64 \\
1.70 \\
1.84 \\
1.78 \\
1.75 \\
1.72 \\
1.66 \\
1.68 \\
1.80 \\
1.74\end{array}$ & $\begin{array}{c}28 \\
\text { Term } \\
30 \\
35 \\
39 \\
29 \\
\text { Term } \\
22 \\
20 \\
37 \\
8\end{array}$ & & $\begin{array}{l}20 \\
27 \\
25 \\
19 \\
15 \\
24 \\
24 \\
19 \\
26 \\
25 \\
27\end{array}$ & $\begin{array}{l}24 \\
29 \\
28 \\
24 \\
22 \\
28 \\
26 \\
24 \\
29 \\
35 \\
35\end{array}$ \\
\hline & & & & & 23 & 28 \\
\hline
\end{tabular}

TABLE III

Some physical characteristics and results of pulmonary function studies in patients with atrial septal defect

\begin{tabular}{|c|c|c|c|c|c|c|c|c|c|c|c|c|}
\hline \multirow[b]{2}{*}{ Subject } & \multirow[b]{2}{*}{ Sex } & \multirow[b]{2}{*}{ Age } & \multirow[b]{2}{*}{$\begin{array}{c}\text { Body } \\
\text { surface } \\
\text { area }\end{array}$} & \multirow[b]{2}{*}{$\begin{array}{l}\text { Vital } \\
\text { capacity }\end{array}$} & \multirow[b]{2}{*}{$\begin{array}{l}\text { Resid- } \\
\text { ual } \\
\text { volume }\end{array}$} & \multirow[b]{2}{*}{$\begin{array}{l}\text { Single- } \\
\text { breath } \\
\mathrm{N}_{2} \text { test }\end{array}$} & \multirow[b]{2}{*}{$\begin{array}{c}\text { Maximal } \\
\text { breathing } \\
\text { capacity }\end{array}$} & \multirow[b]{2}{*}{$\begin{array}{l}\text { Maximal } \\
\text { expiratory } \\
\text { flow rate }\end{array}$} & \multirow[b]{2}{*}{$\begin{array}{l}\text { Maximal } \\
\text { inspiratory } \\
\text { flow rate }\end{array}$} & \multicolumn{3}{|c|}{$\begin{array}{c}\text { Diffusing capacity } \\
(\mathrm{ml} \mathrm{CO} / \mathrm{mm} \mathrm{Hg} / \mathrm{min})\end{array}$} \\
\hline & & & & & & & & & & & Rest & $\begin{array}{l}\text { Exer- } \\
\text { cise } \\
3 \mathrm{mph}\end{array}$ \\
\hline & & years & $m^{2}$ & $\% \mathrm{PN} *$ & $\% \mathrm{PN}$ & $\% \mathrm{~N}_{2}$ & $\% \mathrm{PN}$ & $L / \min$ & $L / \min$ & & & \\
\hline G.P. & $\mathbf{M}$ & 16 & 1.71 & 91 & 143 & 0.3 & 69 & 347 & 300 & & 45 & 48 \\
\hline R.D. & $\mathbf{M}$ & 21 & 1.90 & 117 & 206 & 0.3 & 139 & 350 & 260 & & 70 & 77 \\
\hline G.C. & $\mathbf{M}$ & 37 & 1.52 & 61 & 124 & 2.6 & 83 & 245 & 158 & & 28 & 35 \\
\hline H.H. & $F$ & 35 & 1.37 & 77 & 113 & 0.0 & 92 & 225 & 157 & & 25 & 27 \\
\hline L.A. & F & 48 & 1.78 & 72 & 214 & 0.3 & 69 & 200 & 183 & & 27 & 33 \\
\hline \multirow[t]{2}{*}{ A.F. } & F & 52 & 1.75 & 99 & 88 & 0.2 & 126 & 225 & 211 & & 45 & 50 \\
\hline & & & & & & & & & & Mean & 40 & 45 \\
\hline
\end{tabular}

* $\mathrm{PN}=$ predicted normal.

TABLE IV

Some physical characteristics and results of pulmonary function studies in patients with lung disease

\begin{tabular}{|c|c|c|c|c|c|c|c|c|c|c|c|c|c|}
\hline \multirow[b]{2}{*}{ Subject } & \multirow[b]{2}{*}{ Sex } & \multirow[b]{2}{*}{ Age } & \multirow[b]{2}{*}{$\begin{array}{c}\text { Body } \\
\text { surface } \\
\text { area }\end{array}$} & \multirow[b]{2}{*}{ Diagnosis } & \multirow[b]{2}{*}{$\begin{array}{l}\text { Vital } \\
\text { capacity }\end{array}$} & \multirow[b]{2}{*}{$\begin{array}{c}\text { Resid- } \\
\text { ual } \\
\text { volume }\end{array}$} & \multirow[b]{2}{*}{$\begin{array}{l}\text { Single- } \\
\text { breath } \\
\mathrm{N}_{2} \text { test }\end{array}$} & \multirow{2}{*}{$\begin{array}{l}\text { Maxi- } \\
\text { mal } \\
\text { breath- } \\
\text { ing } \\
\text { capac- } \\
\text { ity }\end{array}$} & \multirow{2}{*}{$\begin{array}{l}\text { Maxi- } \\
\text { mal } \\
\text { expira- } \\
\text { tory } \\
\text { flow } \\
\text { rate }\end{array}$} & \multirow{2}{*}{$\begin{array}{c}\text { Maxi- } \\
\text { mal } \\
\text { inspira- } \\
\text { tory } \\
\text { flow } \\
\text { rate }\end{array}$} & \multicolumn{3}{|c|}{$\begin{array}{l}\text { Diffusing capacity } \\
(\mathrm{ml} \mathrm{CO} / \mathrm{mm} \mathrm{Hg} / \mathrm{min})\end{array}$} \\
\hline & & & & & & & & & & & & Rest & $\begin{array}{c}\text { Exer- } \\
\text { cise } \\
3 \mathrm{mph}\end{array}$ \\
\hline & & years & $m^{2}$ & & $\% \mathrm{PN} *$ & $\% \mathrm{PN}$ & $\% \mathrm{~N}_{2}$ & $\% \mathrm{PN}$ & $L / \min$ & $L / \min$ & & & \\
\hline L.B. & $\mathbf{M}$ & 18 & 1.46 & Fibrosis & 65 & 305 & 6.4 & 63 & 129 & 261 & & 20 & 23 \\
\hline F.S. & $\mathbf{M}$ & 43 & 2.10 & Fibrosis & 70 & 166 & 3.5 & 85 & 250 & 400 & & 16 & 19 \\
\hline H.H. & $F$ & 45 & 1.48 & Fibrosis & 89 & 181 & 2.9 & 135 & 235 & 195 & & 14 & 14 \\
\hline C.S. & $\mathbf{M}$ & 51 & 1.89 & Fibrosis & 47 & 56 & 3.7 & 116 & 290 & 320 & & 6 & 5 \\
\hline L.S. & $\mathrm{F}$ & 53 & 1.59 & Fibrosis & 139 & & 3.9 & 174 & 460 & 295 & & 20 & 20 \\
\hline M.S. & $\mathbf{M}$ & 60 & 1.98 & $\begin{array}{l}\text { Emphysema and } \\
\text { fibrosis }\end{array}$ & 85 & 136 & 2.2 & 55 & 123 & 340 & & 24 & 25 \\
\hline F.M. & $\mathbf{M}$ & 45 & 2.44 & Emphysema & 50 & 340 & 3.1 & 61 & 58 & 220 & & 36 & 33 \\
\hline W.B. & $\mathbf{M}$ & 47 & 2.21 & Emphysema & 84 & 336 & 4.0 & 47 & 103 & 217 & & 28 & 32 \\
\hline L.G. & $\mathbf{M}$ & 50 & 1.97 & Cystic lung disease & 117 & 170 & 2.9 & 73 & 185 & 290 & & 20 & 17 \\
\hline \multirow[t]{2}{*}{ J.V. } & $\mathbf{M}$ & 53 & 2.14 & Cystic lung disease & 97 & 58 & 3.0 & 88 & 480 & 230 & & 9 & 9 \\
\hline & & & & & & & & & & & Mean & 19 & 20 \\
\hline
\end{tabular}

* $\mathrm{PN}=$ predicted normal. 
same manner as in normal subjects. The women exercised at 3 miles per hour.

The physical characteristics and results of pulmonary function studies in six patients with atrial septal defect are listed in Table III. The diagnosis of atrial septal defect was confirmed by cardiac catheterization. These patients exercised at 3 miles per hour.

The physical characteristics and results of pulmonary function studies in ten patients with chronic lung disease are listed in Table IV. The diagnosis was based on clinical findings and pulmonary function studies. These patients exercised at 3 miles per hour. Pulmonary function tests in them and in the patients with atrial septal defect were done according to methods previously described from this laboratory (16).

\section{RESULTS}

Normal subjects. Figure 1 is a plot of the mean change in pulmonary diffusing capacity with exercise at the five levels studied, with increase in pulmonary diffusing capacity plotted against oxygen consumption. At 2 miles per hour, mean oxygen consumption was $665 \mathrm{ml}$ per minute or $350 \mathrm{ml}$ per $\mathrm{m}^{2}$ of body surface area. Some subjects had a slight increase in pulmonary diffusing capacity and others had a slight fall. The mean result was a slight fall in pulmonary diffusing capacity at 2 miles per hour when compared with resting. At 3 miles per hour, the oxygen consumption was $810 \mathrm{ml}$ per minute or $424 \mathrm{ml}$ per $\mathrm{m}^{2}$ of body surface area. All normal subjects had an increase in pulmonary diffusing capacity at this level of exercise, and the mean increase was 4.9 $\mathrm{ml}$ per minute per $\mathrm{mm} \mathrm{Hg}$. With progressive increases in exercise, there was progressive increase in oxygen consumption and pulmonary diffusing

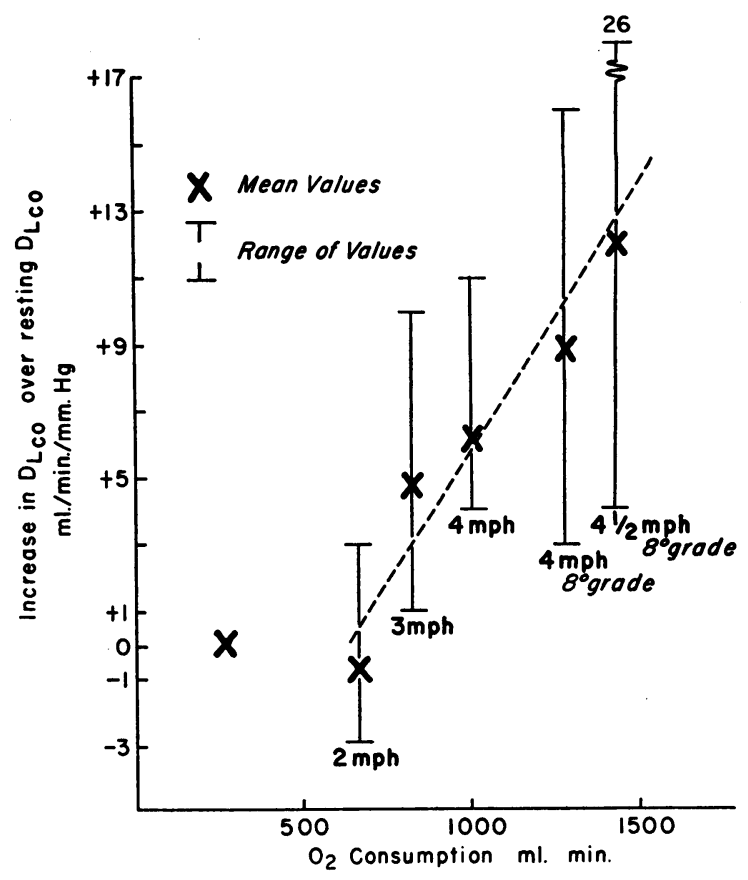

Fig. 1. The increase in pulmonary diffusing CaPACITY WITH VARIOUS LEVELS OF EXERCISE IN NORMAL PERSONS. The rate of walking a treadmill is marked in miles per hour.

capacity. A maximal diffusing capacity was not reached. The values for pulmonary diffusing capacity at rest and exercise for the normal subjects are listed in Table V.

Patients. Resting and exercise diffusing capacity measurements in the eleven pregnant women are shown in Figure 2 and Table II. There was a mean increase in pulmonary diffusing capacity with exercise of $4.8 \mathrm{ml}$ per minute

TABLE V

Diffusing capacity in normal persons at rest and exercise*

\begin{tabular}{|c|c|c|c|c|c|c|c|c|c|c|}
\hline \multirow[b]{2}{*}{ Subject } & \multicolumn{10}{|c|}{ Diffusing capacity in $\mathrm{ml} \mathrm{CO} / \mathrm{mm} \mathrm{Hg} / \mathrm{min}$} \\
\hline & Rest & $\begin{array}{c}\text { Exer- } \\
\text { cise } \\
2 \mathrm{mph}\end{array}$ & Rest & $\begin{array}{l}\text { Exer- } \\
\text { cise } \\
3 \mathrm{mph}\end{array}$ & Rest & $\begin{array}{l}\text { Exer- } \\
\text { cise } \\
4 \mathrm{mph}\end{array}$ & Rest & $\begin{array}{c}\text { Exer- } \\
\text { cise } \\
4 \text { mph, } \\
8 \% \text { grade }\end{array}$ & Rest & $\begin{array}{c}\text { Exer- } \\
\text { cise } \\
4.5 \mathrm{mph} \text {, } \\
8 \% \text { grade }\end{array}$ \\
\hline $\begin{array}{l}\text { N.A. } \\
\text { D.S. } \\
\text { S.D. } \\
\text { M.S. } \\
\text { P.B. } \\
\text { R.C. } \\
\text { R.A. } \\
\text { S.J. } \\
\text { R.R. }\end{array}$ & $\begin{array}{l}41 \\
32 \\
31 \\
36 \\
32\end{array}$ & $\begin{array}{l}44 \\
29 \\
30 \\
37 \\
29\end{array}$ & $\begin{array}{l}21 \\
21 \\
24 \\
22 \\
40 \\
33 \\
29 \\
41 \\
29\end{array}$ & $\begin{array}{l}27 \\
22 \\
29 \\
28 \\
44 \\
37 \\
37 \\
48 \\
32\end{array}$ & $\begin{array}{l}21 \\
19 \\
17 \\
25 \\
37 \\
33 \\
37 \\
36 \\
30\end{array}$ & $\begin{array}{l}25 \\
26 \\
21 \\
31 \\
48 \\
40 \\
44 \\
41 \\
35\end{array}$ & $\begin{array}{l}23 \\
18 \\
19 \\
26 \\
53 \\
41 \\
36 \\
45 \\
27\end{array}$ & $\begin{array}{l}26 \\
27 \\
24 \\
29 \\
69 \\
50 \\
44 \\
58 \\
40\end{array}$ & $\begin{array}{l}21 \\
\\
19 \\
24 \\
53 \\
36 \\
33 \\
45 \\
31\end{array}$ & $\begin{array}{l}34 \\
\\
23 \\
30 \\
67 \\
45 \\
59 \\
59 \\
41\end{array}$ \\
\hline
\end{tabular}

* The rate of walking a treadmill is given in miles per hour. 
Pregnant Women

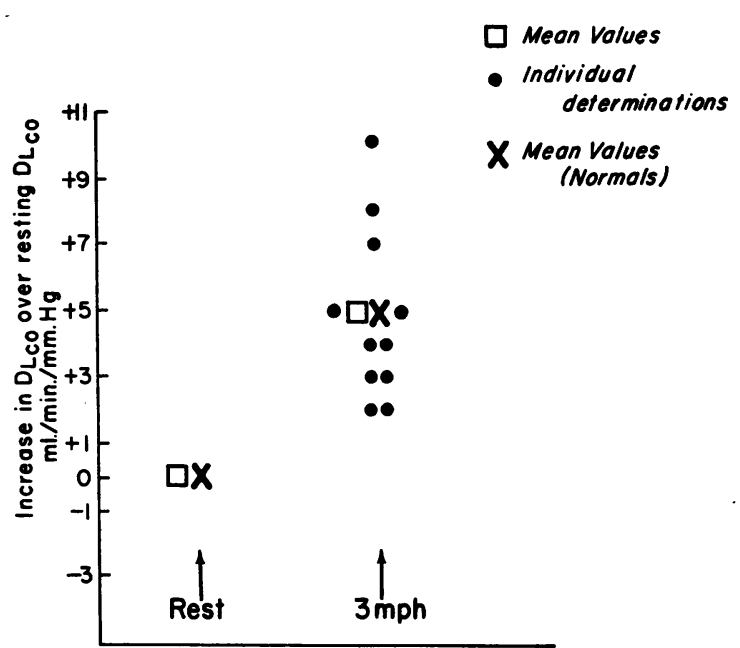

Fig. 2. The increase in PUlmonary Diffusing CAPACITY IN 11 PREGNANT WOMEN AFTER WALKING ON A TREADMILL AT 3 MILES PER HOUR.

per $\mathrm{mm} \mathrm{Hg}$ in these patients; their individual increase was 2 to $10 \mathrm{ml}$ per minute per $\mathrm{mm} \mathrm{Hg}$.

When exercising at 3 miles per hour, the six patients with atrial septal defect had a mean increase in pulmonary diffusing capacity of $5.0 \mathrm{ml}$ per minute per $\mathrm{mm} \mathrm{Hg}$ (Figure 3), and an individual increase of 2 to $7 \mathrm{ml}$ per minute per $\mathrm{mm}$ $\mathrm{Hg}$.

The ten patients with lung disease responded differently (Figure 4 and Table V). Three pa-

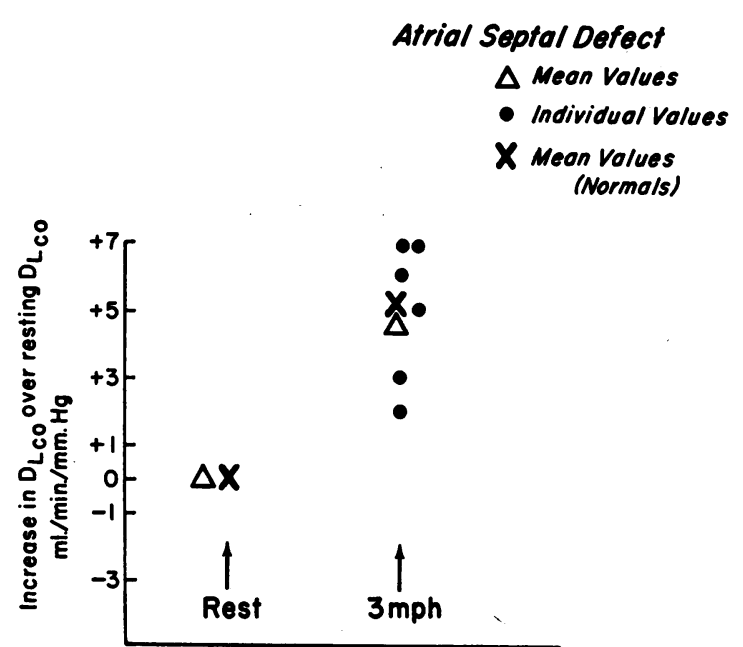

Fig. 3. The increase in PULMONARY diffusing CAPACITY IN 6 PATIENTS WITH ATRIAL SEPTAL DEFECT AFTER WALKING ON A TREADMILL AT 3 MILES PER HOUR.
Patients with Lung Disease

- Mean Values

- Individual Values

$X$ Mean Values

(Normals)

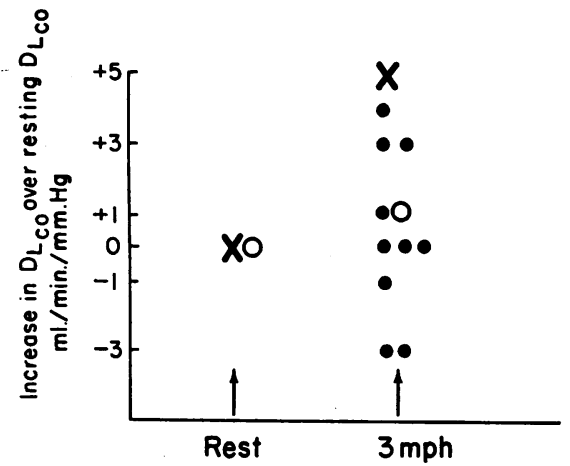

Fig. 4. The change in PUlmonary diffusing CAPACITY IN 10 PATIENTS WITH LUNG DISEASE AFTER EXERCISE ON A TREADMILL AT 3 MILES PER HOUR.

tients had no increase in pulmonary diffusing capacity, three had a fall, and four had a mild increase. The mean increase was $0.8 \mathrm{ml}$ per minute per $\mathrm{mm} \mathrm{Hg}$.

The results are summarized in Figure 5, where the mean values for pulmonary diffusing capacity in absolute units are plotted at rest and at exercise of 3 miles per hour. The patients with atrial septal defect had a large pulmonary diffusing capacity at rest that increased normally with exer-

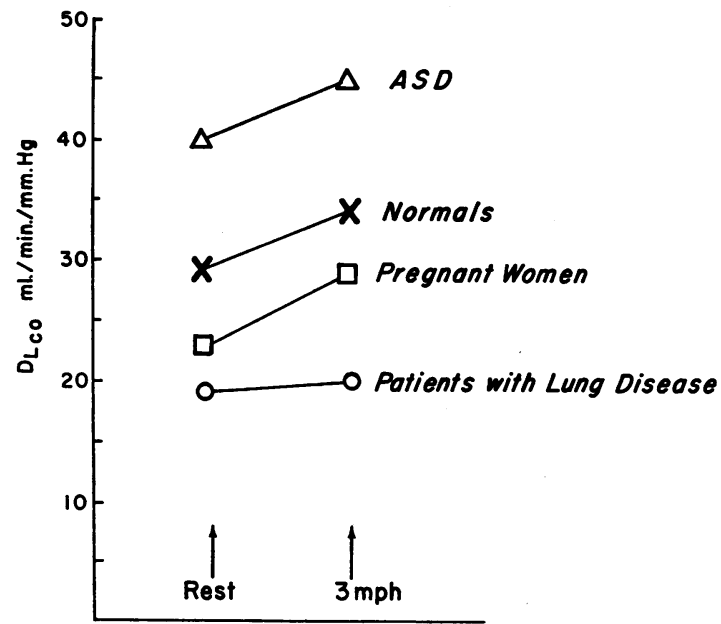

Fig. 5. A PLOT OF THE MEAN VALUES FOR PULMONARY DIFFUSING CAPACITY IN 4 GROUPS OF PATIENTS STUDIED AT REST AND DURING EXERCISE. ASD indicates patients with atrial septal defect. 
cise. The pregnant women, because their preclicted normal values were lower than for the group of normal men and women, started at a lower absolute level than the normal group, but increased in a normal way. Patients with lung disease started with a low value and had an abnormal response to exercise.

\section{DISCUSSION}

When the exercise stimulus is great enough, pulmonary diffusing capacity increases in normal persons and in patients who have the ability to increase the size of the pulmonary capillary bed. Pulmonary diffusing capacity fails to increase in response to an adequate stimulus in some patients with lung disease, presumably because the capillary bed is incapable of enlarging. The normal response of some patients with lung disease to the exercise stimulus suggests that they retain the ability to increase the capillary bed size. These findings are consistent with our anatomical knowledge of the pulmonary capillary bed in disease.

Factors other than increase in the size of the capillary bed that might be responsible for an increase in pulmonary diffusing capacity with exercise are the associated hyperventilation, a difference in the alveolar volume between the resting and exercise states, a fall in the capillary $\mathrm{P}_{\mathrm{O}_{2}}$ with breath-holding, an increase in capillary $\mathrm{P}_{\mathrm{CO}_{2}}$ with breath-holding, and uneven ventilation within the lungs.

Hyperventilation. The effect of hyperventilation on pulmonary diffusing capacity has depended on the method used to measure diffusing capacity. Using the steady state method, Ross, Frayser, and Hickam (7), Turino, Brandfonbrener, and Fishman (9), and MacNamara, Prime, and Sinclair (17) found that hyperventilation produced an increase in the diffusing capacity of the lung. They suggested that the increase in pulmonary diffusing capacity found with exercise depended on hyperventilation. Apthorp and Marshall (15), however, have shown that the value obtained for the measurement of steady state diffusing capacity at rest depended upon the alveolar volume at which the measurement was made. They showed that values obtained for pulmonary diffusing capacity by the steady state method and the breath-holding method were the same when the alveolar volumes were equal. In addition, Apthorp and Marshall
(15) showed, by the steady state method, that exercise produced an increase in pulmonary diffusing capacity greater than that which would be accounted for by the increased ventilation of exercise. An increase in pulmonary diffusing capacity with hyperventilation has not been demonstrated with the breath-holding method (7), presumably because the measurement is made at maximal lung volume. All our measurements were made using the breath-holding method at full inspiration. The hyperpnea of exercise was similar in normal persons, pregnant women, the patients with atrial septal defect, and those with lung disease. We do not believe that the increase in pulmonary diffusing capacity with exercise can be ascribed to hyperventilation, and we are quite sure that hyperventilation does not explain the differences found between normal persons and patients with lung disease.

Alveolar volume. Although Ogilvie and colleagues (6) found that pulmonary diffusing capacity varied little at different alveolar volumes, a number of investigators have found that there is a definite increase in pulmonary diffusing capacity as alveolar volume increases $(11-13,15)$. We were aware that if the alveolar volume at rest was smaller than the alveolar volume during exercise, we might find an increase in pulmonary diffusing capacity that would depend on an increase in alveolar volume only. Because of this, we compared the alveolar volumes during rest and exercise and found them the same within 100 to $200 \mathrm{ml}$ in every case. By having the subject take a maximal inspiration both at rest and during exercise, we were able to duplicate alveolar volumes in these two situations.

Fall in $P_{o_{2}}$ with breath-holding. During the 10 seconds of breath-holding, capillary $\mathrm{P}_{\mathrm{O}_{2}}$ will fall. This can affect the pulmonary diffusing capacity measurement by increasing the reaction rate of carbon monoxide and hemoglobin, and produces an increase in the apparent diffusing capacity of the lungs. If a fall in capillary $\mathrm{P}_{\mathrm{O}_{2}}$ were the only mechanism responsible for the increased pulmonary diffusing capacity with exercise, we would anticipate that patients with lung disease would have as much of an increase in pulmonary diffusing capacity as the normal subjects. Although a fall in pulmonary capillary $\mathrm{P}_{\mathrm{O}_{2}}$ may be partly responsible for the increase in pulmonary diffusing 
capacity observed with exercise, it is not a satisfactory explanation for the differences found between normal persons and patients with lung disease.

Increase in $\mathrm{P}_{\mathrm{CO}_{2}}$ with breathholding. Rankin, McNeill, and Forster (18) have demonstrated an increase in pulmonary diffusing capacity with an increase in alveolar $\mathrm{CO}_{2}$ tension. During the 10second period of breath-holding, both at rest and during exercise, there is probably some increase in alveolar $\mathrm{CO}_{2}$ tension, and it is undoubtedly accentuated during exercise. This increase in alveolar $\mathrm{CO}_{2}$ tension may account for some of the increase in pulmonary diffusing capacity observed with exercise, but it would not account for the difference between normal persons and patients with lung disease.

Uneven distribution of inspired air. A considerable controversy exists about the interpretation of measurements of pulmonary diffusing capacity in patients with chronic obstructive emphysema. Apthorp and Marshall (15) have summarized the reasons the steady state method gives results that are often too low, whereas the single-breath method gives results that are often too high. In spite of the obvious problems, most workers agree with Rankin (19) that in the individual patient, the values are quite reproducible and that the measurement provides useful information concerning the capillary bed in the lung. Our patients with fibrosis, who have less difficulty with the distribution of inspired air than the patients with emphysema, responded to exercise in the same fashion as those with emphysema. Since the measurement of pulmonary diffusing capacity at rest and exercise was made at maximal inspiration, air was probably distributed in a similar way in both situations.

Fall in pulmonary diffusing capacity with exercise in patients with lung disease. Some of the patients with lung disease had a fall in pulmonary diffusing capacity with exercise. This decrease in pulmonary diffusing capacity cannot be explained on the basis of a difference in alveolar volume because the alveolar volumes were the same when the measurements were made. Exercise might produce edema of the alveolar capillary membrane in patients with lung disease. Such a change would have to occur within 2 minutes and not change appreciably with further exercise. In our patients with lung disease, the individual determinations of pulmonary diffusing capacity made at 2, 4, and 6 minutes after the start of exercise were all quite close together. If edema of the pulmonary capillary membrane were to develop, we would expect a progressive fall in pulmonary diffusing capacity with time.

It is possible that the patients with lung disease who are somewhat breathless in the performance of this test, which involves exercising on the treadmill and holding one's breath for 10 seconds after a maximal inspiration, are performing a partial Valsalva maneuver, obstructing the return of blood to the chest and thereby decreasing the size of the pulmonary capillary bed. Ogilvie and colleagues (6) demonstrated a slight fall in pulmonary diffusing capacity with a considerable increase in intrathoracic pressure. Apparently the normal persons, the pregnant women, and the patients with atrial septal defect were able to perform the maneuvers entailed in the pulmonary diffusing capacity test without increasing intrathoracic pressure.

\section{SUMM ARY}

1. We have demonstrated the magnitude of increase in pulmonary diffusing capacity in normal subjects over a range of exercise levels.

2. Mild exercise is not always associated with an increase in pulmonary diffusing capacity in normal subjects. In them, exercise on a treadmill at 3 miles per hour, producing an oxygen consumption of $810 \mathrm{ml}$ per minute, was always associated with an increase in pulmonary diffusing capacity.

3. Pregnant women, who presumably have a normal pulmonary capillary bed, and patients with atrial septal defect, who have a large resting pulmonary capillary bed, respond to exercise with an increase in pulmonary diffusing capacity identical to that of normal subjects.

4. The pulmonary diffusing capacity in some patients with lung disease fails to increase in response to exercise. This failure suggests a restricted pulmonary capillary bed.

\section{ACKNOWLEDGMENTS}

The authors acknowledge the technical help of Mrs. Sharmaine Davelis, Mrs. Mary Goedken, Mrs. Kay 
Starbuck, Miss Diana Sprague, Mr. Donald Laughlin, and Mr. Robert Clark. We are indebted to Dr. Walter M. Kirkendall and Dr. William B. Bean for critical review of the work, and to Mrs. Nancee Blum for preparation of the manuscript.

\section{REFERENCES}

1. Adams, R. W., and Bedell, G. N. Pulmonary diffusing capacity during rest and exercise: A study of normals and persons with atrial septal defect, pregnancy, and pumonary disease (abstract). Clin. Res. 1961, 9, 246.

2. Krogh, M. The diffusion of gases through the lungs of man. J. Physiol. (Lond.) 1915, 49, 271.

3. Lilienthal, J. L., Jr., Riley, R. L., Proemmel, D. D., and Franke, R. E. An experimental analysis in man of the oxygen pressure gradient from alveolar air to arterial blood during rest and exercise at sea level and at altitude. Amer. J. Physiol. 1946, 147, 199.

4. Filley, G. F., MacIntosh, D. J., and Wright, G. W. Carbon monoxide uptake and pulmonary diffusing capacity in normal subjects at rest and during exercise. J. clin. Invest. 1954, 33, 530.

5. Bates, D. V., Boucot, N. G., and Dormer, A. E. The pulmonary diffusing capacity in normal subjects. J. Physiol. (Lond.) 1955, 129, 237.

6. Ogilvie, C. M., Forster, R. E., Blakemore, W. S., and Morton, J. W. A standardized breath holding technique for the clinical measurement of the diffusing capacity of the lung for carbon monoxide. J. clin. Invest. 1957, 36, 1.

7. Ross, J. C., Frayser, R., and Hickam, J. B. A study of the mechanism by which exercise increases the pulmonary diffusing capacity for carbon monoxide. J. clin. Invest. 1959, 38, 916.

8. Forster, R. E. Exchange of gases between alveolar air and pulmonary capillary blood: Pulmonary diffusing capacity. Physiol. Rev. 1957, 37, 391.

9. Turino, G. M., Brandfonbrener, M., and Fishman, A. P. The effect of changes in ventilation and pulmonary blood flow on the diffusing capacity of the lung. J. clin. Invest. 1959, 38, 1186.

10. Rosenberg, E., and Forster, R. E. Changes in diffusing capacity of isolated cat lungs with blood pressure and flow. J. appl. Physiol. 1960, 15, 883.

11. Marks, A., Cugell, D. W., Cadigan, J. B., and Gaensler, E. A. Clinical determination of the diffusing capacity of the lungs. Comparison of methods in normal subjects and patients with "alveolar-capillary block” syndrome. Amer. J. Med. 1957, 22, 51.

12. Marshall, R. A comparison of methods of measuring the diffusing capacity of the lungs for carbon monoxide. Investigation by fractional analysis of the alveolar air. J. clin. Invest. 1958, 37, 394.

13. Shephard, R. J. "Breath-holding" measurement of carbon monoxide diffusing capacity. Comparison of field test with steady-state and other methods of measurement. J. Physiol. (Lond.) 1958, 141, 408.

14. Cadigan, J. B., Marks, A., Ellicott, M. F., Jones, R. H., and Gaensler, E. A. An analysis of factors affecting the measurement of pulmonary diffusing capacity by the single breath method. J. clin. Invest. 1961, 40, 1495.

15. Apthorp, G. H., and Marshall, R. Pulmonary diffusing capacity: A comparison of breath-holding and steady state methods using carbon monoxide. J. clin. Invest. 1961, 40, 1775.

16. Bedell, G. N., Wilson, W. R., and Seebohm, P. M. Pulmonary function in obese persons. J. clin. Invest. 1958, 37, 1049.

17. MacNamara, J., Prime, F. J., and Sinclair, J. D. The increase in diffusing capacity of the lungs on exercise. An experimental and clinical study. Lancet 1960, 1, 404.

18. Rankin, J., McNeill, R. S., and Forster, R. E. Influence of increased alveolar carbon dioxide tension on pulmonary diffusing capacity for $\mathrm{CO}$ in man. J. appl. Physiol. 1960, 15, 543.

19. Rankin, John. Evaluation of Alveolar Capillary Diffusion in Clinical Cardiopulmonary Physiology, New York, Grune and Stratton 1960, 624-634. 